\title{
Science and politics
}

\author{
Science must remain non-partisan, but it cannot - and should not - be disengaged from the \\ society it serves.
}

On 22 April 2017, which coincided with Earth Day, thousands of scientists, science enthusiasts, and members of the general public took to the streets in over 600 locations around the globe to march for science. According to its organizers the March for Science network - the event aimed to promote the visibility of science in the public arena. From the global south all the way to the North Pole, marchers chanted: "What do we want? Evidence-based policy. When do we want it? After peer review."

The march and its effectiveness were broadly debated both before the march and in its aftermath. Nobody disagreed with the fundamental aims of the event, but is marching the best way to speak up for science's role in society and policymaking? For some, it was an opportunity for visible civic engagement, a chance to speak up for and celebrate science. For others, marching was too closely associated with protest politics and was likely to be perceived as a partisan event, especially in the United States - "another liberaldemocrat progressive's complaining-fest" (http://go.nature.com/2ps5gl1).

The scientific community is largely politically liberal. In the United States, a survey carried out by the Pew Research Center showed that among those scientists surveyed, 55\% identified as Democrats, $32 \%$ identified as independents, whereas only $6 \%$ said they are Republicans (http://go.nature.com/2olt6Ph). At the same time, however, the public perceives scientists as non-partisan: $64 \%$ of Americans think of scientists as neither liberal nor conservative (http://go.nature. com/2oCnaha). There is much to be said about the need for diversity, including ideological diversity, among researchers (see Perspective by Medin et al. in this issue; article no. 0088). Regardless, scientists have clearly been successful in communicating that their commitment to science and the quest for facts trump personal political or ideological leanings.

Science must be non-partisan and available to anybody who needs it or can benefit from it, be they governments or

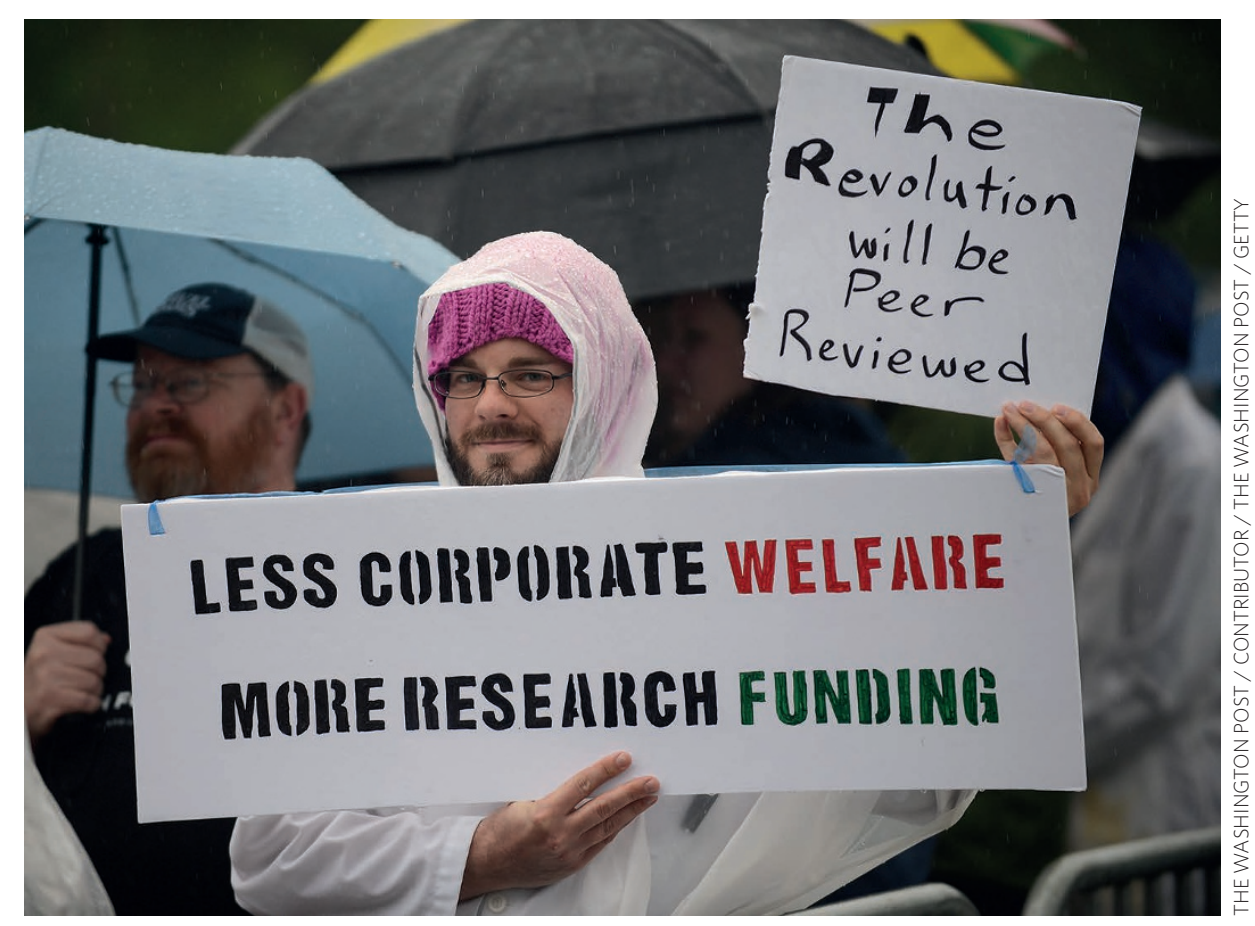

members of the general public. Scientific facts are needed by all governments left, right, or centre - to inform their decision-making. Making science a partisan issue risks harm to all involved.

At the same time, science cannot be apolitical: it is not produced in a vacuum and it is a key part of the affairs of the polis. Scientists need to be embedded in the societies they serve, engage with the public, and advocate for evidence-based policymaking and for the interests of science (including funding and the right to be heard).

\section{"Society should worry when geeks have to demonstrate!"}

The best way to advocate for science isn't a settled matter because the scientific community faces an unprecedented challenge. The threat isn't that evidence is politicized, a phenomenon with a long history that political scientists and sociologists have been researching for decades. Rather, the threat is that scientific evidence is rendered irrelevant by rhetoric - in the United States, United Kingdom, Turkey, and elsewhere, the political establishment is edging out scientific evidence from public policy discourse. "People in this country have had enough of experts," said Brexit campaigner Michael Gove just before the referendum that decided the fate of the United Kingdom's membership in the European Union (http://go.nature. com/2obxz6w). This unprecedented threat of being silenced leads to unprecedented action. "Society should worry when geeks have to demonstrate!" said the sign of a marcher for science in Amsterdam (http://go.nature.com/2p8KcwX).

Is it possible that adopting the politics of protest will erode the public's perception of scientists as non-partisan, impartial questers of truth? We do not know the answer, but like everything else in science, this is a question that can be settled with facts. 